\title{
Penerapan Metode Regulatory Impact Assessment Dalam Penyusunan Peraturan Daerah di Kota Kendari
}

\author{
Application of Regulatory Impact Assessment Method in Formulating Regional \\ Regulations in Kendari City
}

\section{Rahman Hasima ${ }^{1}$}

1. Universitas Halu Oleo, Indonesia.E-mail: rahmanhasima@uho.ac.id

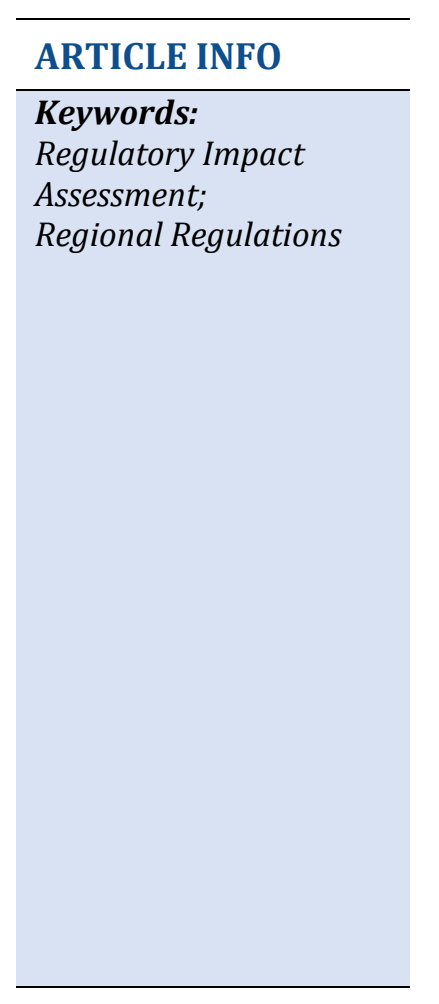

\section{INFO ARTIKEL}

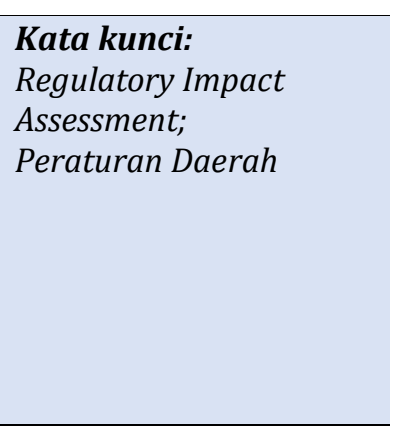

\begin{abstract}
The purpose of this research is to know the urgency of implementing the Regulatory Impact Assessment method in drafting local regulations in Kendari city and local regulatory mechanisms through the Regulatory Impact Assessment method. The research methods used are normative legal research methods with a of Approach and conceptual approach approach. The results showed that: 1) factors that inhibit the process of drafting local regulation in the city of Kendari, among others: a) legal substance (legal substance): The absence of guidelines for the establishment of regional Regulation Program (PROPEMPERDA) stipulated by the Local Representative Council of Kendari and some local regulations of the city of Kendari do not include academic manuscripts, b) legal structure: lack of understanding of the planning team, especially in the House of Representatives The people of the city of Kendari on the theory, methodology, and engineering of regulatory drafting and less involving stakeholders in the drafting of local regulations, C) Legal culture: the lack of community participation in The preparation of local regulations in Kendari City and 2) the mechanism of regional regulation through the Regulatory Impact Assessment method is as follows: 1) Formulation of problems, 2) identification of objectives, 3) alternative measures, 4) analysis of benefits and costs, 5) Option selection, and 6) policy implementation strategy, all phases are done by public consultation. After all stages, the report is made in the form of Regulatory Impact Assessment Statement (RIAS) document.
\end{abstract}


peraturan Dewan Perwakilan Rakyat Daerah Kota Kendari dan beberapa peraturan daerah Kota Kendari tidak menyertakan naskah akademik, b) Struktur hukum (legal structure): kurangnya pemahaman tim perancang khususnya di Dewan Perwakilan Rakyat Daerah Kota Kendari tentang teori, metodologi, dan teknik perancangan peraturan perundang-undangan dan kurang melibatkan stakeholder dalam penyusunan peraturan daerah, c) Budaya hukum (legal culture): kurangnya partisipasi masyarakat dalam penyusunan peraturan daerah di Kota Kendari. Sehingga diperlukan suatu metode baru dalam penyusunan peraturan daerah di Kota Kendari melalui metode Regulatory Impact Assessment. Adapun Mekanisme penyusunan peraturan daerah melalui metode Regulatory Impact Assessment adalah sebagai berikut: 1) Perumusan Masalah, 2) Identifikasi tujuan, 3) Alternatif Tindakan, 4) Analisis manfaat dan biaya, 5) Pemilihan Opsi, dan 6) Strategi implementasi kebijakan, semua tahapan dilakukan dengan Konsultasi Publik. Setelah semua tahapan dilakukan disusunlah laporan dalam bentuk Dokumen Regulatory Impact Assessment Statement (RIAS).

\section{Pendahuluan}

Negara Kesatuan Republik Indonesia dibagi atas daerah-daerah provinsi, dan daerah provinsi itu dibagi atas kabupaten dan kota, yang tiap-tiap provinsi, kabupaten, dan kota itu mempunyai pemerintahan daerah, yang diatur dengan undang-undang1. Sebagai konsekuensi dari pembagian daerah dan pemberian kewenangan berupa otonomi daerah, maka setiap pemerintahan daerah berhak menetapkan peraturan daerah dan peraturanperaturan lain untuk melaksanakan otonomi dan tugas pembantuan. Pemerintahan daerah dalam menyelenggarakan urusan pemerintahan yang menjadi wewenangnya yang diberikan oleh UUD 1945 (Pasal 18 ayat 6), salah satunya adalah untuk membentuk peraturan daerah dan peraturan pelaksanaan lainnya.

Pemberian otonomi kepada daerah dan kewenangan dalam menetapkan peraturan daerah dimaksudkan sebagai upaya untuk memberikan keleluasaan kepada daerah sesuai dengan kondisi lokalistisnya. Selain itu juga dimaksudkan untuk mendekatkan jarak antara pembuat peraturan daerah (pejabat daerah) dengan rakyat didaerahnya sehingga terbangun suasana komunikatif yang intensif dan harmonis di antara keduanya. Artinya keberadaan rakyat di daerah sebagai subjek pendukung utama demokrasi mendapat tempat dan saluran untuk berpartisipasi terhadap berbagai peraturan daerah yang dikeluarkan/dihasilkan oleh pemerintahan daerah.

Kewenangan daerah yang semakin besar dengan adanya otonomi daerah membuat pemerintah daerah memberlakukan berbagai peraturan daerah yang dibuat untuk mengatur kegiatan ekonomi dan sosial di daerahnya. Persoalan muncul ketika kebanyakan peraturan itu kemudian dinilai oleh pemangku kepentingan di daerah ataupun di pusat tidak sesuai dengan tujuan pemberian otonomi itu sendiri. Otonomi daerah dilaksanakan karena pemerintah ingin mempercepat perbaikan kemakmuran masyarakat di daerah. Namun, sayangnya karena pertimbangan kepentingan sempit dan

1 Pasal 18 ayat (1) UUD NRI 1945 
jangka pendek, justru peraturan yang dibuat oleh daerah kabupaten/kota atau provinsi tidak mampu mendorong pembangunan yang berkelanjutan di daerah.

Berdasarkan hasil penelusuran yang dilakukan di berbagai media dapat ditunjukkan bahwa sejak tahun 2003 hingga tahun 2009, banyak Perda yang direkomendasikan untuk dibatalkan dan direvisi. Bulan Agustus 2003 Kompas menulis: "Depdagri menilai 7.000 Perda tidak layak". Hingga medio April 2005 terdapat 448 Perda yang direkomendasikan untuk dibatalkan dan direvisi. Pada bulan Maret 2006 bertambah lagi, Perda yang dibatalkan mencapai 930 Perda. hingga pertengahan Agustus 2009, pemerintah sudah membatalkan 3.455 Perda yang mengatur pajak dan retribusi daerah. Alasan utamanya adalah Perda-Perda tersebut menimbulkan ekonomi biaya tinggi yang menghambat iklim investasi di daerah ${ }^{2}$. Hal ini juga terjadi di Sulawesi Tenggara khususnya di Kota Kendari.

Berdasarkan data dari Kementerian Dalam Negeri tahun 2016, Khusus di wilayah Sulawesi Tenggara (Sultra), ada 46 Perda yang dibatalkan dari 11 kota/kabupaten. Ratarata perda yang dibatalkan adalah Perda tentang Retribusi. Di Kota Kendari terdapat 3 Perda yang dibatalkan yaitu, Perda Pajak Rumah Kos No. 5 Tahun 2005, Perda Retribusi Jalan ke Pelabuhan No. 7 Tahun 2005 dan Perda Retribusi Jasa Umum Khusus yang Mengatur Jenis Retribusi Penggantian Biaya Cetak KTP \& Akta Catatan Sipil No. 2 Tahun $2012^{3}$.

Dalam menyelesaikan persoalan-persoalan yang terjadi terkait dengan peraturan daerah, pemerintah Indonesia telah mengeluarkan Undang-Undang Nomor 15 Tahun 2019 tentang Perubahan Atas Undang-Undang Nomor 12 Tahun 2011 tentang Pembentukan Peraturan Perundang-Undangan. Undang-Undang ini dimaksudkan untuk menciptakan ketertiban dan perbaikan kualitas peraturan perundang-undangan di Indonesia yang salah satu sasarannya adalah Perda. Berbagai persyaratan dan ketentuan telah dicantumkan dalam undang-undang ini yaitu terkait dengan sistem, asas, tata cara penyiapan dan pembahasan, teknik penyusunan dan pengundangannya.

Hal ini sejalan dengan visi misi Kota Kendari yaitu "Mewujudkan Kota Kendari Kota Layak Huni Yang Berbasis Ekologi, Informasi dan Teknologi” yang kemudian dijabarkan dalam 3 (tiga) misi pembangunan kota Kendari yaitu: 1). Meningkatkan kualitas pelayanan masyarakat 2). Pembangunan Infrastruktur, dan 3). Menata wajah Kota Kendari. Dalam mewujudkan misi Meningkatkan kualitas pelayanan masyarakat, salah satunya dilakukan dengan cara Meningkatkan tata kelola pemerintahan yang baik yang didukung oleh regulasi dan sistem informasi pemerintahan yang baik serta SDM yang berkualitas.

Namun demikian, proses yang dibangun berdasarkan aturan atau regulasi yang ada akan sulit tanpa adanya perubahan paradigma berpikir bagi penyusun peraturan daerah.

2 Kontan, 20 Agustus 2009. Terkait dengan Perda bermasalah berkenaan dengan pelaku usaha dapat juga dilihat pada Komite Pemantauan Pelaksanaan Otonomi Daerah (KPPOD), Daya Saing Investasi Kabupaten/Kota di Indonesia, 2005: Persepsi Dunia Usaha (Jakarta: KPPOD, 2006), 39.

3 Daftar Perda/Perkada dan Peraturan Menteri Dalam Negeri yang Dibatalkan/Revisi, 2016, diakses November 17, 2019,

https://www.kemendagri.go.id/media/filemanager/2016/06/21/b/a/batal_perda_21_juni_2016.pdf. 
Dengan demikian kebutuhan akan kerangka berpikir dan pengalaman yang baik untuk penyusunan peraturan daerah dari berbagai pihak yang telah teruji keberadaan dan praktiknya menjadi penting untuk dikaji dan diterapkan di Indonesia khususnya di Kota Kendari.

Saat ini terdapat banyak alat (tools) untuk menganalisis peraturan perundang-undangan, salah satunya peraturan daerah dengan menggunakan metode Regulatory Impact Assessment (RIA) dengan tujuan agar peraturan daerah yang dianalisis dan yang akan dibentuk menjadi peraturan daerah yang baik dan efektif. Regulatory Impact Assessment selanjutnya disebut RIA, merupakan suatu metode yang digunakan dalam penyusunan suatu aturan yang secara prinsip dapat mengakomodasi langkah-langkah yang harus dijalakan dalam penyusunan suatu aturan. Metode ini mulai popular di awal tahun 2000an, dan banyak digunakan di negara-negara maju.

Di Indonesia terdapat beberapa daerah yang menerapkan RIA, baik hanya sekedar melakukan pengenalan RIA, maupun yang secara konsisten menerapkan RIA dalam proses pembentukan Perda ${ }^{4}$. Hal ini menunjukkan bahwa di Sulawesi Tenggara khususnya di Kota Kendari belum menerapkan bahkan memperkenalkan RIA.

Berdasarkan penjelasan di atas, penulis perlu mengkaji mengenai "Penerapan Metode Regulatory Impact Assessment Dalam Penyusunan Peraturan Daerah di Kota Kendari". Adapun yang menjadi permasalahan adalah faktor-faktor apa yang menghambat penyusunan peraturan daerah di Kota Kendari dan Bagaimana mekanisme penyusunan peraturan daerah melalui metode Regulatory Impact Assessment.

\section{Metode}

Penelitian ini menggunakan metode penelitian hukum normatif. Penelitian hukum normatif adalah penelitian yang dilakukan dengan cara meneliti bahan pustaka ${ }^{5}$. dengan menggunakan pendekatan perundang-undangan (statute aprroach) dan pendekatan konseptual (conceptual aprroach). Pendekatan perundang-undangan (statute aprroach) dilakukan dengan menelaah semua undang-undang dan regulasi yang bersangkut paut dengan isu hukum yang sedang ditangani sedangkan Pendekatan Konseptual (Conceptual Approach) beranjak dari pandangan-pandangan dan doktrin-doktrin yang berkembang di dalam ilmu hukum. dengan mempelajari pandang-pandangan dan doktrin-doktrin di dalam ilmu hukum, peneliti akan menemukan ide-ide yang melahirkan pengertianpengertian hukum, konsep-konsep hukum, dan asas-asas hukum relevan dengan isu yang dihadapi. Pemahaman akan pandangan-pandangan dan doktrin-doktrin tersebut merupakan sandaran bagi peneliti dalam membangun suatu argumentasi hukum dalam memecahkan isu yang dihadapi ${ }^{6}$. Pada penelitian hukum normatif bahan pustaka sebagai

4 Agus Ediawan, "Pengenalan RIA" (Medan: Training RIA untuk Pemerintah Kabupaten Aceh Besar pada Program RIA Aceh-The Asia Foundation, 2009).

5 Soerjono Soekanto dan Sri Mamudji, Penelitian Hukum Normatif: Suatu Tinjauan Singkat, 1 ed. (Jakarta: Rajawali Pers, 2014), 13.

6 Peter Mahmud Marzuki, Penelitian Hukum (Jakarta: Kencana Prenada Media Group, 2011), 24. 
data dasar yang dalam ilmu penelitian digolongkan sebagai data sekunder ${ }^{7}$. Di dalam penelitian hukum, data sekunder mencakup: pertama, bahan hukum primer yaitu bahanbahan hukum yang mengikat, dan terdiri dari norma dasar (pembukaan UUD 1945), Peraturan Dasar (Batang Tubuh UUD 1945, dan Ketetapan-ketetapan MPR), peraturan perundang-undangan, kedua, bahan hukum sekunder, yang memberikan penjelasan mengenai bahan hukum primer, seperti hasil-hasil penelitian, hasil karya dari kalangan hukum, dan seterusnya, dan ketiga, bahan hukum tertier, yakni bahan hukum yang memberikan petunjuk maupun penjelasan terhadap bahan hukum primer dan sekunder, seperti kamus bahasa Indonesia, ataupun kamus hukum. Dengan teknik pengumpulan bahan hukum melalui penelitian kepustakaan (library research). dan studi lapangan di Bagian Hukum Sekretariat Daerah Kota Kendari dan Bagian Hukum Sekretariat DPRD Kota Kendari. Setelah data terkumpul kemudian dianalisis dengan metode deskriptif kualitatif.

\section{Kondisi Penyusunan Peraturan Daerah di Kota Kendari}

Produk hukum daerah berdasarkan Permendagri Nomor 80 Tahun 2015 tentang Pembentukan Produk Hukum Daerah meliputi produk hukum berbentuk Peraturan meliputi perda atau nama lainnya, Perkada, Peraturan Bersama Kepala Daerah, Peraturan DPRD, dan berbentuk Keputusan meliputi Keputusan Kepala Daerah, Keputusan DPRD, Keputusan Pimpinan DPRD dan Keputusan Badan Kehormatan DPRD. Secara hierarki, kedudukan Peraturan Daerah berada pada urutan pertama dan menjadi acuan peraturan yang berada di bawahnya.

Proses pembentukan Perda dalam siklusnya diawali dengan perencanaan yang dalam konteks pemerintah daerah disebut dengan Program Pembentukan Peraturan Daerah yang disingkat Propemperda (dulu bernama Program Legislasi Daerah) sesuai dengan ketentuan Pasal 239 UU Nomor 23 Tahun 2014 tentang Pemerintahan Daerah. Program pembentukan peraturan daerah adalah instrumen perencanaan program pembentukan peraturan daerah provinsi atau peraturan daerah kabupaten/kota yang disusun secara terencana, terpadu, dan sistematis (Pasal 1 angka 10 UU No.15 Tahun 2019 tentang Perubahan Atas UU No.12 Tahun 2011 tentang Pembentukan Peraturan PerudangUndangan).

Program Pembentukan Peraturan Daerah (Propemperda) menjadi bagian penting dalam rangka menentukan arah politik hukum pemerintah daerah dalam membangun peraturan perundang-undangan yang dibutuhkan untuk mendukung pencapaian program pembangunan yang telah disusun dalam rencana pembangunan daerah baik jangka panjang maupun menengah.

Propemperda selain disusun dalam bentuk lima tahunan juga dilakukan dalam bentuk tahunan yang mengacu pada rencana kerja pembangunan (RKP) daerah tahunan. Oleh

7 Soekanto dan Mamudji, Penelitian Hukum Normatif: Suatu Tinjauan Singkat, 24. 
karenanya, rancangan Perda yang masuk dalam program pembentukan peraturan daerah menjadi prioritas pembahasan Perda tahunan yang bersangkutan.

Dalam Pasal 403 UU No. 23 Tahun 2014 tentang Pemerintahan Daerah menyatakan bahwa Semua ketentuan mengenai program legislasi daerah dan badan legislasi daerah yang sudah ada sebelum Undang-Undang ini berlaku harus dibaca dan dimaknai sebagai program pembentukan Perda (Propemperda) dan badan pembentukan Perda (Bapemperda), sepanjang tidak bertentangan dengan Undang-Undang.

Sesuai dengan alur proses pembentukannya, perencanaan merupakan proses yang pertama yang dalam hal ini diformulasikan dalam bentuk Program Pembentukan Peraturan Daerah. Mengusulkan Raperda untuk dibahas pada masa sidang dalam agenda tahunan, pembentukan peraturan daerah merupakan proses penting yang termasuk juga sebagai proses politik antara eksekutif dan legislatif. Proses inilah yang menentukan apakah sebuah inisiatif Perda menjadi prioritas atau bukan pada tahun yang bersangkutan. Hal ini sejalan dengan Pasal 239 UU Nomor 23 Tahun 2014 tentang Pemerintahan Daerah yang menyatakan bahwa Perencanaan Penyusunan Perda dilakukan dalam suatu Program Pembentukan Peraturan Daerah. Program Pembentukan Perda merupakan pedoman dan pengendali penyusunan Peraturan Daerah yang mengikat lembaga yang berwenang (Pemerintah Daerah dan DPRD) dalam membentuk Peraturan Daerah.

Proses selanjutnya setelah perencanaan adalah penyusunan Raperda. Untuk mempersiapkan Raperda dilakukan dengan pembentukan Tim Raperda yang berada di bawah koordinasi Kepala Bagian Hukum. Tim inilah yang bertugas berkoordinasi dengan Organisasi Perangkat Daerah (OPD) terkait dan menyusun naskah akademis dan draf hukum Raperda. Untuk kebutuhan penyusunan tersebut, tim Raperda dibantu analisa dan kajian atas inisiasi kebutuhan Perda ini oleh Tim Pengkajian Perda yang bekerja di bawah Sub Bagian Perundang-undangan.

Program pembentukan peraturan daerah Kota Kendari tahun 2017 berdasarkan SK DPRD Kota Kendari No.27/DPRD/2017 tentang Pembentukan Perda Kota Kendari Tahun 2017 berjumlah 26 Raperda yang terdiri dari 10 usulan dari eksekutif dan 16 dari inisiatif DPRD Kota Kendari ${ }^{8}$. Adapun daftar Propemperda Kota Kendari tahun 2017 dapat dilihat pada tabel 1 berikut ini.

Tabel 1. Daftar Propemperda Kota Kendari Tahun 2017.

\begin{tabular}{llcc}
\hline \multicolumn{1}{c}{ NAMA RANPERDA } & \multicolumn{2}{c}{ USULAN } & KETERANGAN \\
\cline { 3 - 3 } NO. & \multicolumn{2}{c}{ DPRD } & PEMKOT \\
\hline 1 & Bantuan Hukum Kepada Masyarakat Miskin & $\checkmark$ & \\
2 & Perlindungan Pemotongan Sapi & $\checkmark$ & \\
3 & Penataan Pemakaian Rumah Susun Sewa & $\checkmark$ & \\
& (Rusunawa) & \multicolumn{2}{c}{$\checkmark$} \\
4 & Penyelenggaraan dan Pengelolaan Perpustakaan & $\checkmark$
\end{tabular}

8 Daftar Program Pembentukan Peraturan Daerah Kota Kendari Tahun 2017 
5 Pemusatan, Pengaturan, Penataan Perdagangan

6 Kawasan Kendari Beach (Kebi) sebagai Pusat Kuliner Kota Kendari

7 Pemusatan, Pengaturan, Penataan Pedagang Barang Bekas

8 Pemekaran Kelurahan Gunung Jati

9 Tempat Pemakaman Umum Kelurahan Gunung Jati

10 Permainan Ketangkasan

11 Pengaturan Pengoperasian Mobil Pengangkut Kontainer

12 Penataan Area Parkir Tempat Publik

13 Teluk Kendari sebagai Smart Point

14 Pengaturan dan Peningkatan Kapasitas Pelaku Usaha Mikro

15 Pengembangan Potensi Kepemudaan

16 Pengelolaan Air Berbasis Masyarakat

17 Perubahan Atas Perda No. 10 Tahun 2013 tentang RPJMD Kota Kendari

18 Kerja sama Daerah

19 Perlindungan dan Pengembangan Ekonomi Kreatif

20 Perlindungan Hutan Mangrove dan Hutan Pantai

21 Pedoman Pengelolaan Kekayaan Daerah

22 Pengelolaan Analisis Mengenai Dampak Lingkungan Hidup, Upaya Pengelolaan Lingkungan Hidup, Upaya Pemantauan Lingkungan Hidup

23 Perubahan Atas Perda No. 3 Tahun 2013 tentang Retribusi Izin Gangguan

24 Perubahan Kedua Atas Perda No. 2 Tahun 2012 tentang Retribusi Jasa Umum

25 Perubahan Kedua Atas Perda No.3 Tahun 2012 tentang Retribusi Jasa Usaha

26 Perubahan Kedua Atas Perda No.4 Tahun 2013 tentang Retribusi Izin Usaha Perikanan

Perda No.7 Tahun 2018 tentang RPJMD Kota Kendari Tahun 2017-2022

$\checkmark \quad$ Perda No.2 Tahun 2018

$\checkmark \quad$ Perda No.1 Tahun 2018

$\checkmark \quad$ Dibatalkan Karena Kewenangan Provinsi

$\checkmark \quad$ Perda No.3 Tahun 2018 tentang Pengelolaan Barang Milik Daerah

$\checkmark \quad$ Belum ditetapkan

Belum ditetapkan

Perda No. 6 Tahun 2018

Perda No.5 Tahun 2018

Belum ditetapkan

Berdasarkan data di atas menunjukkan bahwa ada 26 Raperda yang diusulkan baik dari pemerintah daerah maupun inisiatif DPRD Kota Kendari hanya 6 Raperda yang disahkan atau ditetapkan sebagai Peraturan Daerah (Perda) yaitu:

1) Peraturan Daerah Kota Kendari Nomor 7 Tahun 2018 tentang Rencana Pembangunan Jangka Menengah Daerah (RPJMD) Kota Kendari Tahun 2017-2022;

2) Peraturan Daerah Kota Kendari Nomor 2 Tahun 2018 tentang Kerjasama Daerah;

3) Peraturan Daerah Kota Kendari Nomor 1 Tahun 2018 tentang Perlindungan dan Pengembangan Ekonomi Kreatif; 
4) Peraturan Daerah Kota Kendari Nomor 3 Tahun 2018 tentang Pengelolaan Barang Milik Daerah;

5) Peraturan Daerah Kota Kendari Nomor 6 Tahun 2018 tentang Perubahan Kedua Atas Peraturan Daerah Nomor 3 Tahun 2012 tentang Retribusi Jasa Umum;

6) Peraturan Daerah Kota Kendari Nomor 5 Tahun 2018 tentang Perubahan Kedua Atas Peraturan Daerah Nomor 3 Tahun 2012 tentang Retribusi Jasa Usaha.

Kemudian Pada Tahun 2018, berdasarkan SK DPRD Kota Kendari No.2/DPRD/2018 tentang Program Pembentukan Peraturan Daerah Kota Kendari Tahun 2018 berjumlah 11 Raperda yang terdiri dari 3 usulan dari pemerintah Kota Kendari dan 8 berasal dari inisiatif DPRD Kota Kendari ${ }^{9}$. Adapun daftar Propemperda Kota Kendari Tahun 2018 dapat dilihat pada tabel 2. berikut ini.

Tabel 2. Daftar Propemperda Kota Kendari Tahun 2018.

\begin{tabular}{|c|c|c|c|c|}
\hline \multirow{2}{*}{ NO. } & \multirow{2}{*}{ NAMA RANPERDA } & \multicolumn{2}{|c|}{ USULAN } & \multirow{2}{*}{ KETERANGAN } \\
\hline & & DPRD & PEMKOT & \\
\hline 1 & Organisasi Kemasyarakatan & $\checkmark$ & & \\
\hline 2 & $\begin{array}{l}\text { Pasar Rakyat, Pusat Perbelanjaan dan Toko } \\
\text { Swalayan }\end{array}$ & $\checkmark$ & & \\
\hline 3 & Izin Tinggal Penduduk Musiman di Kota Kendari & $\checkmark$ & & \\
\hline 4 & Kota Layak Anak & $\checkmark$ & & \\
\hline 5 & Pengembangan Kota Tangguh Bencana & $\checkmark$ & & \\
\hline 6 & Wisata Halal & $\checkmark$ & & \\
\hline 7 & $\begin{array}{l}\text { Perlindungan Hak-Hak Adat dan Budaya } \\
\text { Masyarakat Adat Kerajaan Laiwoi }\end{array}$ & $\checkmark$ & & \\
\hline 8 & Hak-Hak Penyandang Disabilitas & $\checkmark$ & & \\
\hline 9 & $\begin{array}{l}\text { Perubahan Ketiga Atas Perda No.3 Tahun } 2012 \\
\text { tentang Retribusi Jasa Usaha }\end{array}$ & & $\checkmark$ & Perda No.9 Tahun 2018 \\
\hline 10 & Rencana Induk Pembangunan Kepariwisataan & & $\checkmark$ & Perda No.1 Tahun 2019 \\
\hline 11 & Tanda Daftar Usaha Kepariwisataan & & $\checkmark$ & Perda No.2 Tahun 2019 \\
\hline
\end{tabular}

Berdasarkan data di atas menunjukkan bahwa ada 11 Raperda Tahun 2018 yang diusulkan baik dari usulan pemerintah daerah maupun inisiatif DPRD Kota Kendari hanya 3 Raperda yang disahkan atau ditetapkan sebagai Peraturan Daerah (Perda) yaitu:

1) Peraturan Daerah Kota Kendari Nomor 9 Tahun 2018 tentang Perubahan Ketiga Atas Perda No.3 Tahun 2012 tentang Retribusi Jasa Usaha;

2) Peraturan Daerah Kota Kendari Nomor 1 Tahun 2019 tentang Rencana Induk Pembangunan Kepariwisataan;

3) Peraturan Daerah Kota Kendari Nomor 2 Tahun 2019 tentang Tanda Daftar Usaha Kepariwisataan.

Berdasarkan data di atas menunjukkan bahwa penyusunan peraturan daerah di Kota Kendari tidak berjalan dengan baik karena berdasarkan daftar program pembentukan peraturan daerah tahun 2017 dan 2018 terdapat 37 Raperda yang diusulkan baik dari pemerintah daerah maupun inisiatif DPRD Kota Kendari hanya 9 Raperda yang ditetapkan

9 Daftar Program Pembentukan Peraturan Daerah Kota Kendari Tahun 2018 
atau disahkan sebagai peraturan daerah. Hal ini ditunjukkan dengan banyaknya raperda yang diusulkan tidak disahkan sebagai perda dengan berbagai alasan antara lain: bertentangan dengan peraturan perundang-undangan yang lebih tinggi, tumpang tindih kewenangan antara pemerintah provinsi dan kota, serta urgensi peraturan daerah dengan kebutuhan masyarakat kota Kendari.

Kemudian dari 37 Raperda yang diusulkan pada tahun 2017 dan 2018 terdapat 5 Raperda tidak disertakan dengan naskah akademik dengan alasan hanya perubahan peraturan daerah sehingga cukup dengan penjelasan saja sesuai dengan ketentuan Pasal 56 dan Pasal 63 Undang-Undang Nomor 12 Tahun 2011 tentang Pembentukan Peraturan Perundang-Undangan jo. Pasal 22 ayat (1) Peraturan Menteri Dalam Negeri Nomor 80 Tahun 2015 tentang Pembentukan Produk Hukum Daerah bahwa ranperda baik yang berasal dari DPRD atau yang berasal dari Kepala Daerah disertai dengan penjelasan atau keterangan dan/atau naskah akademik.

Adapun raperda yang tidak memiliki naskah akademik antara lain sebagai berikut:

1) Raperda Perubahan Atas Perda No. 3 Tahun 2013 tentang Retribusi Izin Gangguan;

2) Raperda Perubahan Kedua Atas Perda No. 2 Tahun 2012 tentang Retribusi Jasa Umum;

3) Raperda Perubahan Kedua Atas Perda No.3 Tahun 2012 tentang Retribusi Jasa Usaha;

4) Raperda Perubahan Kedua Atas Perda No.4 Tahun 2013 tentang Retribusi Izin Usaha Perikanan;

5) Raperda Perubahan Ketiga Atas Perda No.3 Tahun 2012 tentang Retribusi Jasa Usaha.

\section{Faktor-faktor yang Menghambat Penyusunan Peraturan Daerah di Kota Kendari}

Hukum dibuat untuk dilaksanakan. Oleh karena itu, tidaklah mengherankan apabila P. Scholten mengatakan bahwa "manakala hukum tidak pernah dilaksanakan, maka tidak lagi disebut sebagai hukum"10. Hukum itu sendiri dalam wujudnya sebagai peraturan jelas tidak dapat melakukan semua itu. Dengan demikian menjadi relevan untuk dibahas mengenai faktor-faktor yang mempengaruhi penegakkan hukum.

Faktor-faktor tersebut menurut Soerjono Soekanto adalah sebagai berikut: faktor kaidah hukum/peraturan itu sendiri, faktor petugas/penegak hukum, faktor sarana atau fasilitas, faktor masyarakat dan faktor budaya11. Pendapat tersebut sejalan dengan yang dikemukakan oleh Lawrent Friedman yang menyatakan bahwa penegakan hukum dipengaruhi oleh tiga hal yaitu substansi hukum (legal subtance), Struktur Hukum (legal structure), budaya hukum (legal culture).

Faktor-faktor tersebut di atas saling berkaitan, karena merupakan esensi dari penegakan hukum serta merupakan tolak ukur dari efektivitas penegakan hukum. Faktor-faktor

Satjipto Rahardjo, Hukum dan Masyarakat (Bandung: Angkasa, 1986), 69.

11 Soerjono Soekanto, Faktor-Faktor Yang Mempengaruhi Penegakan Hukum (Jakarta: Rajawali Pers, 2008), 9. 
tersebut apabila dihubungkan dengan pembentukan peraturan daerah di Kota Kendari, maka dapat dianalisis sebagai berikut:

\subsection{Substansi Hukum (Legal Subtance)}

Dalam pembentukan peraturan daerah dikenal adanya Program Pembentukan Peraturan Daerah (Propemperda) dalam tahap perencanaan. Sampai saat ini di Kota Kendari belum memiliki pengaturan yang tegas dan jelas melalui Peraturan DPRD Kota Kendari tentang tata cara atau mekanisme penyusunan program pembentukan peraturan daerah. Dalam UU 12 Tahun 2011 tentang Pembentukan Peraturan Perundang-Undangan jo. UU Nomor 23 Tahun 2014 tentang Pemerintahan Daerah hanya menjelaskan bahwa "Rancangan Peraturan Daerah disusun berdasarkan program legislasi daerah/Program Pembentukan Peraturan Daerah" tanpa mengatur secara rinci materi-materi yang dimasukkan dalam Program Pembentukan Peraturan Daerah dan pentingnya Program Pembentukan Peraturan Daerah. Berbeda dengan program legislasi nasional yang telah mempunyai pengaturan yang memadai mengenai substansi, prosedur penyusunan serta pengelolaannya. Tidak diaturnya secara rinci materi-materi yang dimasukkan dalam Program Pembentukan Peraturan Daerah dan pentingnya Program Pembentukan Peraturan Daerah menyebabkan Program Pembentukan Peraturan Daerah oleh DPRD dianggap bukanlah sesuatu yang diharuskan dalam pembentukan peraturan daerah. Padahal secara tegas dalam Pasal 39 Undang-Undang Nomor 12 Tahun 2011 Pembentukan Peraturan Perundang-Undangan disebutkan bahwa perencanaan penyusunan peraturan daerah Kabupaten/Kota dilakukan dalam Prolegda/propemperda Kabupaten/Kota.

Selain itu, dalam penyusunan peraturan daerah harus menyertakan naskah akademik sebelum dilakukan pembentukan perda sebagaimana diatur dalam Pasal 56 dan Pasal 63 Undang-Undang Nomor 12 Tahun 2011 tentang Pembentukan Peraturan PerundangUndangan jo. Pasal 22 ayat (1) Pasal 22 ayat (1) Peraturan Menteri Dalam Negeri Nomor 80 Tahun 2015 tentang Pembentukan Produk Hukum Daerah, ranperda baik yang berasal dari DPRD atau yang berasal dari Kepala Daerah disertai dengan penjelasan atau keterangan dan/atau naskah akademik.

Sebagaimana telah dikemukakan di atas, adanya Naskah Akademik bukan (atau sampai saat ini belum diatur secara tegas) sebagai suatu keharusan dalam proses pembentukan peraturan daerah, akan tetapi keberadaan Naskah Akademik sangat diperlukan dalam proses pembentukan peraturan daerah.

Dalam naskah akademik menelaah 3 (tiga) permasalahan substansi, yaitu dapat menjawab pertanyaan mengapa diperlukan Perda baru, lingkup materi kandungan dan komponen utama Perda, dan proses yang akan digunakan untuk menyusun dan mengesahkan Perda. Ketiga hal tersebut merupakan hal-hal yang paling mendasar dalam proses pembentukan peraturan daerah. 
Naskah akademik juga memaparkan alasan-alasan, fakta atau latar belakang tentang halhal yang mendorong disusunnya suatu masalah sehingga dipandang sangat penting dan mendesak diatur dalam peraturan daerah. Manfaat dari data atau informasi yang dituangkan dalam latar belakang bagi pembentuk peraturan daerah itu, yakni bahwa para pihak pembentuk tersebut dapat mengetahui dengan pasti tentang mengapa perlu dibuat sebuah peraturan daerah dan apakah peraturan daerah tersebut memang diperlukan oleh masyarakat. Namun yang terjadi di Kota Kendari beberapa raperda yang dihasilkan tanpa melalui kajian dalam bentuk laporan naskah akademik dan juga terkadang Raperda sudah ditetapkan dalam Propemperda baru dilakukan kajian akademis terhadap raperda tersebut. Hal ini menyebabkan ketika peraturan daerah dikaji ternyata bertentangan dengan peraturan perundang-undangan yang lebih tinggi bahkan bukan kewenangan dari pemerintah daerah Kota Kendari.

Pembentukan peraturan daerah di Kota Kendari harus membuat program pembentukan peraturan daerah yang jelas dan terencana sehingga kepastian hukum dalam rangka tertib administrasi. Mencermati kasus di Kota Kendari, perlu adanya pengkajian ulang terhadap peraturan daerah agar tidak bertentangan dengan Undang-Undang Nomor 15 Tahun 2019 tentang Perubahan Atas Undang-Undang Nomor 12 Tahun 2011 Tentang Pembentukan Peraturan Perundang-undangan dan Peraturan Menteri Dalam Negeri Nomor 120 Tahun 2018 tentang Perubahan Atas Peraturan Menteri Dalam Negeri Nomor 80 Tahun 2015 Tentang Pembentukan Produk Hukum Daerah. Hal ini dimaksudkan agar dapat menemukan suatu rumusan atau kajian hukum yang komprehensif terhadap suatu rancangan peraturan daerah yang akan dibentuk secara tepat dan bersifat bottom-up atau mencerminkan keinginan dari masyarakat luas.

\subsection{Struktur Hukum (Legal Structure)}

Dalam proses pembentukan peraturan daerah di Kota Kendari, para perancang atau pembentuk peraturan daerah minim akan pemahaman atas teori, metodologi, dan teknik perancangan peraturan perundang-undangan serta dapat secara jelas menerjemahkan kebijakan-kebijakan pemerintah menjadi peraturan daerah yang dapat dilaksanakan secara efektif. Akibat dari hal-hal tersebut, maka tidak mengherankan bila para perancang peraturan daerah khususnya dari pihak DPRD kembali pada kebiasaan yang bermasalah ketika merancang atau membentuk peraturan daerah, yaitu dengan menyadur atau menyalin peraturan daerah lain berdasarkan kompromi keinginan dari kelompokkelompok kepentingan dominan dalam masyarakat maupun DPRD serta SKPD itu sendiri. Selain itu, kurang melibatkan stakeholder dalam penyusunan peraturan daerah.

Partisipasi dan pelibatan masyarakat dalam rancangan Perda adalah sebuah keniscayaan. Hal ini melekat erat dengan konsep demokrasi, sebagaimana dikemukakan oleh Philipus M. Hadjon yang disebut dengan demokrasi partisipasi yang muncul di tahun $1961^{12}$.

12 Mahendra Putra Kurnia et al., Pedoman Naskah Akademik PERDA Partisipatif(Urgensi, Strategi, dan Proses Bagi Pembentukan Perda yang Baik) (Yogyakarta: Kreasi Total Media, 2007), 22. 
Dalam konsep ini rakyat mempunyai hak untuk ikut memutuskan dalam proses pengambilan keputusan pemerintahan. Akibatnya, partisipasi masyarakat kurang aktif dalam proses perencanaan, perancangan, pembahasan sampai pada tahap penetapan dan pengundangan perda dari anggota DPRD sehingga proses pembentukan suatu perda hanya bersifat formalitas dan prosedural belaka. Hal ini dapat dilihat dari 37 Raperda yang diajukan pada tahun 2017 dan 2018 sebanyak 9 Raperda saja yang ditetapkan dan diundangkan dalam lembaran daerah. Oleh sebab itu, perlu adanya pembinaan terhadap kompetensi dan pelatihan dibidang perancangan baik teknik maupun metodologi penyusunan peraturan perundang-undangan secara berkala bagi semua pihak terkait/para perancang khususnya anggota DPRD Kota Kendari dengan cara menjalin kerja sama dengan Kementerian Hukum dan HAM wilayah Sulawesi Tenggara sehingga dapat meningkatkan kualitas para pihak dalam proses pembentukan perda di Kota Kendari. Dengan demikian, perlu disediakan anggaran lebih untuk kegiatan pelatihan dan peningkatan kualitas SDM para perancang khususnya anggota DPRD sehingga dapat meningkatkan kemampuan atau pemahaman mengenai teknik, metodologi pembentukan peraturan daerah dari tahap perencanaan sampai pada tahap pengundangan.

\subsection{Budaya Hukum (Legal Culture)}

Dalam proses pembentukan peraturan daerah, baik dimulai dari tahap perencanaan, perancangan, pembahasan, penetapan dan pengundangan sampai pada tahap sosialisasi, pemerintah daerah bersama dengan DPRD Kota Kendari masih cenderung menutup diri dari pihak luar khususnya masyarakat. Padahal dalam pembentukan peraturan daerah peran serta dari masyarakat sangat dibutuhkan untuk menghasilkan suatu peraturan daerah yang dikehendaki oleh masyarakat luas. Ruang partisipasi masyarakat mestinya harus ada di setiap tahapan pembentukan peraturan daerah. Dengan demikian diharapkan akan lahir peraturan daerah yang partisipatif. Sebagaimana dijelaskan Ibnu Tricahyo bahwa negara selalu dipasangkan dengan warga negara dan di mana ada Negara di situ selalu ada warga atau rakyat yang mengikutinya ${ }^{13}$, oleh sebab itu sistem ini harus terus berjalan dalam sistem pemerintahan. Maka sebagaimana ditegaskan Jazim Hamidi, bahwa dalam penyelenggaraan negara, negara (state) dan masyarakat tidak bisa dipisahkan secara parsial14.

Pada dasarnya keikutsertaan dan partisipasi masyarakat di dalam proses pembentukan peraturan daerah telah diatur dalam Pasal 96 UU Nomor 12 Tahun 2011 tentang Pembentukan Peraturan Perundang-Undangan. Ketentuan ini juga berarti dalam pembentukan suatu peraturan daerah harus terdapat prosedur yang memungkinkan masyarakat untuk berperan aktif di dalam proses pembentukan peraturan daerah. Dalam tahap perencanaan dan perancangan peraturan daerah di DPRD Kota Kendari tidak didahului dengan penelitian untuk menemukan permasalahan apa yang harus dan

13 Ibnu Tricahyo, "Urgensi Pengaturan tentang Pelayanan Publik," Makalah tidak dipublikasikan (2005).

14 Jazim Hamidi, "Paradigma Baru Pembentukan dan Analisis Peraturan Daerah (Studi atas Perda Pelayanan Publik dan Perda Keterbukaan Informasi Publik)," Jurnal Hukum IUS QUIA IUSTUM 18, no. 3 (2011): 336363. 
dibentuk ke dalam peraturan daerah. DPRD melalui anggota-anggotanya hanya mengamati dari luar saja masalah serta isu-isu yang berkembang dalam kondisi sosial masyarakat. Setelah itu pihak DPRD merumuskan sendiri peraturan seperti apa yang akan dihasilkan dengan disertai penjelasan atau keterangan sebagai dasar dalam membentuk peraturan daerah. Sejatinya, penelitian terhadap permasalahan yang muncul perlu dilakukan melalui cara-cara legal, seperti Focus Group Disscussion (FGD), kunjungan kerja, seminar, lokakarya atau diskusi dengan masyarakat langsung di lapangan untuk menemukan rumusan yang baik dalam merencanakan dan merancang suatu rancangan peraturan daerah. Oleh sebab itu, ruang partisipasi masyarakat harus ada di setiap tahapan pembentukan peraturan daerah. Dengan demikian, diharapkan akan lahir peraturan daerah yang patisipatif.

\section{Penyusunan Peraturan Daerah Melalui Metode Regulatory Impact Assessment}

RIA (Regulatory Impact Assessment) adalah sebuah metode yang secara sistematis dan konsisten mengkaji pengaruh yang ditimbulkan oleh tindakan pemerintah, mengkomunikasikan informasi kepada para pengambil keputusan ${ }^{15}$. RIA pada dasarnya digunakan untuk menilai regulasi dalam hal: relevansi antara kebutuhan masyarakat dan sasaran kebijakan, kebutuhan terhadap intervensi pemerintah, efisiensi antara input dan output, efektivitas antara sasaran kebijakan dan hasil, keberlanjutan antara kebutuhan masyarakat dan hasil sebelum diterapkannya atau diubahnya suatu regulasi. Dengan menggunakan metode RIA diharapkan regulasi yang ada semakin baik, mendukung bagi iklim usaha khususnya bagi regulasi terkait usaha dan menciptakan keserasian regulasi secara umum yang pada akhirnya memberikan dampak pada peningkatan kesejahteraan masyarakat.

Adapun tahapan penyusunan peraturan daerah melalui metode Regulatory Impact Assessment (RIA) adalah sebagai berikut ${ }^{16}$ :

Tahap 1: Perumusan Masalah. Tahap awal adalah pemetaan masalah yang relevan dengan tujuan dan substansi regulasi serta didukung dengan data dan fakta lapangan.

Dalam hampir semua kasus, pemerintah menerbitkan kebijakan karena ingin menyelesaikan suatu masalah. Dalam tahap ini analis kebijakan antara lain ingin mengetahui: Apakah dalam mengeluarkan kebijakan, pemerintah telah memahami masalah yang sebenarnya? Apakah masalah yang ingin diselesaikan benar-benar ada? Atau hanya gejalanya? Apakah tidak terdapat masalah yang lebih mendasar? Apakah akar penyebab timbulnya masalah? Dan bagaimana persepsi para stakeholders (pihak yang terkait) terhadap masalah tersebut?

15 Asian Development Bank, Regulatory Impact Assessment (RIA) Guide Book (Jakarta: Asian Development Bank, 2002), 7.

16 Nasokah, "Implementasi Regulatory Impact Assessment (RIA) Sebagai Upaya Menjamin Partisipasi Masyarakat Dalam Penyusunan Peraturan Daerah," Jurnal Hukum IUS QUIA IUSTUM 15, no. 3 (2008): 443-458. 
Tahap 2: Identifikasi Tujuan. Dalam tahap ini analis kebijakan berusaha mengetahui sasaran yang ingin dicapai pemerintah melalui penerbitan kebijakan. Dalam beberapa kasus, sasaran suatu kebijakan tentu saja adalah untuk menyelesaikan 'masalah' yang sudah diidentifikasi pada tahap tersebut di atas. Namun dalam banyak kasus, suatu 'masalah' mungkin cukup pelik dan rumit sehingga tidak bisa diselesaikan hanya dengan satu tindakan (kebijakan) saja. Dalam keadaan demikian, maka kebijakan pemerintah biasanya dibuat memang hanya ditujukan untuk mengatasi sebagian dari masalah yang dihadapi. Oleh karena itu, analis kebijakan harus mengidentifikasikan dengan jelas sasaran yang ingin dicapai oleh kebijakan tersebut.

Pertanyaan yang perlu dicarikan jawabannya, antara lain, Apakah tujuan (sasaran) pemerintah dalam menerbitkan kebijakan? Apakah sasaran kebijakan tersebut untuk menyelesaikan sebagian dari, atau keseluruhan, permasalahan yang dihadapi? (problem biasanya cukup kompleks, sehingga diperlukan beberapa kebijakan untuk menyelesaikan problem secara menyeluruh). Selain itu, analis juga perlu melihat apakah pemerintah memiliki kewenangan mengeluarkan kebijakan tersebut dan apakah kebijakan tersebut konsisten dengan undang-undang dan peraturan lainnya.

Tahap 3: Alternatif Tindakan. Pada tahap ini, analis kebijakan me-review pengembangan alternatif tindakan (opsi) yang dapat digunakan untuk mencapai tujuan dan sasaran yang telah diidentifikasi. Fokus review dalam tahap ini adalah melihat apakah pemerintah telah mempertimbangkan seluruh opsi (alternatif tindakan) yang tersedia. Analis kebijakan juga harus memperhatikan apakah terdapat cara (alternatif tindakan) lain yang lebih baik dan lebih jelas, yang dapat digunakan pemerintah untuk mencapai tujuannya? Bagaimana dengan alternatif tidak melakukan apa-apa (do nothing)? Dengan melihat alternatif penyelesaian masalah lainnya, kita dapat membandingkan dan mempertimbangkan alternatif manakah yang lebih baik dalam mencapai hasil yang diinginkan.

Tahap 4: Analisis Manfaat dan Biaya. Dalam tahap ini, analis kebijakan melakukan assessment atas manfaat dan biaya (keuntungan dan kerugian) untuk setiap opsi atau alternatif tindakan yang penting, dilihat dari sudut pandang pemerintah, masyarakat, konsumen, pelaku usaha, dan ekonomi secara keseluruhan.

Tahap 5: Pemilihan Opsi. Setelah mempertimbangkan berbagai kemungkinan opsi tindakan, dan setelah membandingkan berbagai biaya dan manfaat dari opsi tersebut, maka tahap selanjutnya adalah memilih opsi tindakan yang terbaik untuk mencapai sasaran dan menyelesaikan masalah yang telah dirumuskan sebelumnya. Fungsi analis dalam tahap ini adalah memastikan bahwa pemerintah telah membandingkan semua costs/benefits dan memilih opsi yang paling efisien dan efektif.

Tahap 6: Strategi Implementasi. Setelah opsi dipilih, tahap selanjutnya adalah merumuskan strategi untuk mengimplementasikan kebijakan di lapangan. Strategi implementasi mencakup penatausahaan (administrasi) kebijakan, sosialisasi kebijakan, dan monitoring pelaksanaan kebijakan. 
Sebagai catatan, RIA sangat menekankan proses partisipatif, karena itu pada setiap tahapan perlu melibatkan stakeholder melalui proses konsultasi publik. Publik atau masyarakat adalah pihak yang harus didengar suaranya karena mereka yang pada akhirnya akan menerima dampak, baik dan buruk, dengan adanya kebijakan tersebut.

Secara sistematis tahapan penyusunan peraturan daerah melalui metode Regulatory Impact Assessment (RIA) dapat dilihat pada Gambar 1. berikut ini:

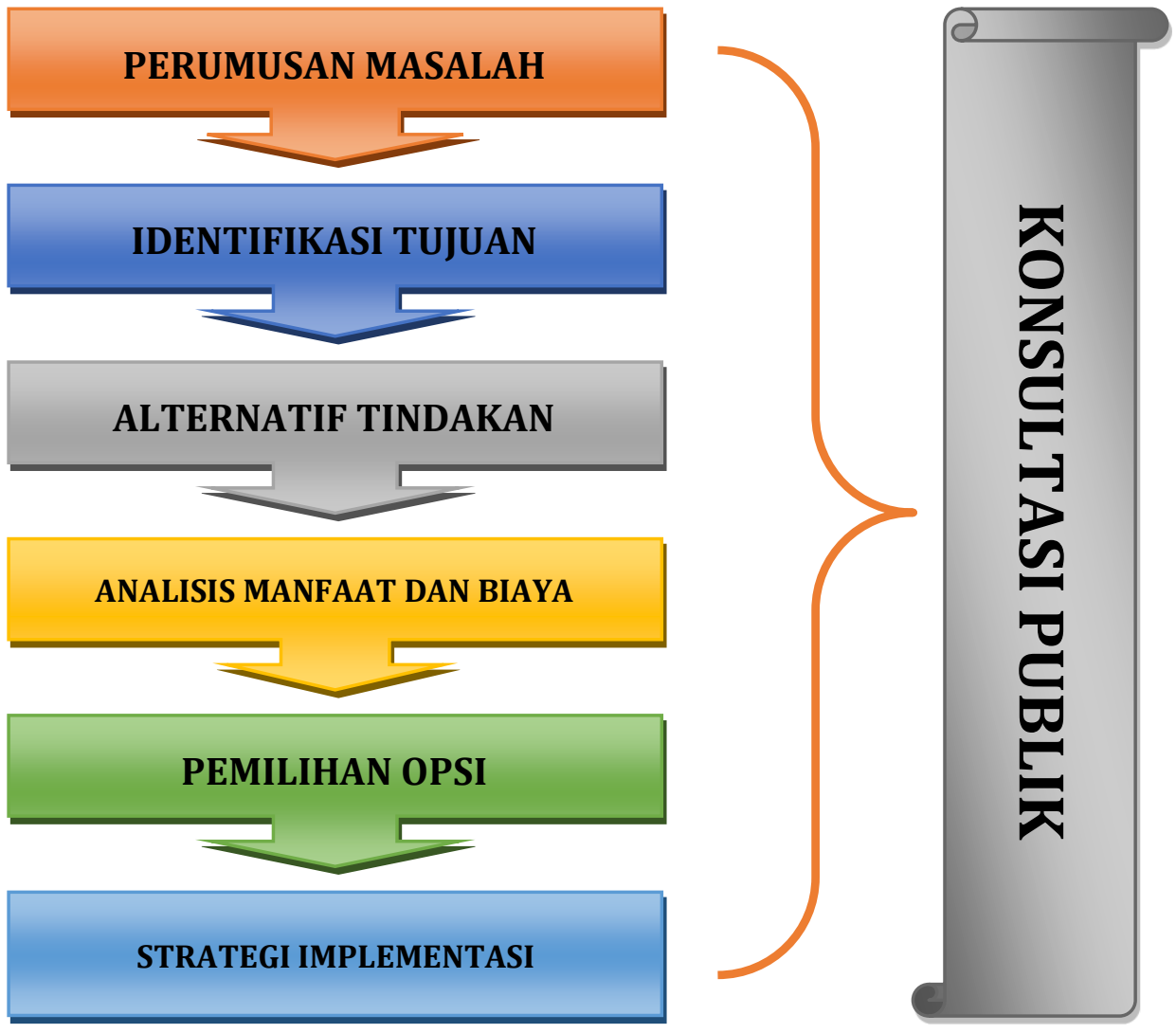

Gambar 1. Tahapan Metode Regulatory Impact Assessment (RIA).

Selanjutnya langkah atau tahapan akhir RIA adalah laporan RIA atau lebih dikenal dengan nama RIA (regulatory impact assessment) atau RIS (regulatory impact statement). RIA diterbitkan sebagai pendamping ranperda atau revisi ranperda yang sedang dibentuk. Sebagai pendamping, RIA memberi penjelasan atau keterangan dengan sistematika, antara lain; alasan regulasi tersebut diterbitkan, sasaran regulasi, adanya opsi yang dipertimbangkan, perbandingan manfaat dan biaya (kerugiannya) dengan adanya regulasi tersebut dan stakeholders yang dilibatkan dalam kegiatan konsultasi.

RIA berfungsi sebagai alat penentu pengambilan keputusan yang secara sistematis dan konsisten mengkaji pengaruh yang ditimbulkan oleh tindakan pemerintah dan mengkomunikasikan informasi kepada para pengambil keputusan.

Selain itu, RIA juga berfungsi untuk memastikan pilihan kebijakan yang paling efektif dan efisien yang diambil oleh pengambil kebijakan melalui kajian terhadap pengaruh yang 
ditimbulkan oleh pengambil kebijakan. Metode RIA pada dasarnya digunakan untuk menilai suatu regulasi dalam hal ${ }^{17}$ :

1. Relevansi antara kebutuhan masyarakat dan sasaran kebijakan;

2. Kebutuhan terhadap intervensi pemerintah;

3. Efisiensi antara input dan output;

4. Keberlanjutan antara kebutuhan masyarakat dan hasil sebelum diterapkannya atau diubahnya suatu regulasi.

Metode RIA memberikan beberapa kegunaan yang cukup signifikan dalam proses penentuan kebijakan sebagai berikut ${ }^{18}$ :

1. Memberikan alasan perlunya intervensi pemerintah;

2. Memberikan alasan regulasi adalah alternatif terbaik;

3. Memberikan alasan bahwa regulasi memaksimumkan manfaat sosial bersih dengan biaya minimum;

4. Mendemonstrasikan bahwa konsultasi publik telah cukup dilaksanakan;

5. Menunjukkan bahwa mekanisme kepatuhan dan implementasi yang sesuai telah ditetapkan.

Ada tiga syarat yang harus dipenuhi untuk memastikan optimalnya penerapan metode RIA dalam penyusunan peraturan daerah untuk mewujudkan tata kelola peraturan yang baik (good regulatory governance) yaitu: adanya kemauan politik (political will) pemegang kekuasaan politik (eksekutif dan legislatif) untuk memperbaiki kualitas peraturan daerah, pelembagaan metode dalam proses pembentukan peraturan daerah dan adanya instrumen sebagai alat pembentukan peraturan daerah.

Dengan terlaksananya ketiga syarat tersebut akan terbangun kualitas peraturan daerah yang mampu menjawab masalah yang terjadi dimasyarakat dan memberikan dampak positif dibandingkan dengan biaya yang dikeluarkan dalam menyelesaikan persoalan yang terjadi dimasyarakat.

Berdasarkan pemaparan di atas, penerapan metode RIA dalam penyusunan peraturan daerah akan memberikan memastikan dua hal pokok yaitu menjamin kerangka berpikir secara logis dan sistematis dalam membangun argumentasi kebutuhan dibentuknya suatu peraturan daerah dan menjamin terselenggaranya konsultasi publik yang baik kepada stakeholders.

\section{Kesimpulan}

Faktor-faktor yang menghambat penyusunan peraturan daerah di Kota Kendari antara lain: a) Substansi hukum (legal subtance): belum adanya panduan penyusunan program pembentukan peraturan daerah (propemperda) yang ditetapkan melalui peraturan

17 Asian Development Bank, Indonesian Regulatory Review Manual (Jakarta: Asian Development Bank dan Departemen Perindustrian dan Perdagangan, 2003), 11.

18 Ibid. 
Dewan Perwakilan Rakyat Daerah Kota Kendari dan beberapa peraturan daerah Kota Kendari tidak menyertakan naskah akademik, b) Struktur hukum (legal structure): kurangnya pemahaman tim perancang khususnya di Dewan Perwakilan Rakyat Daerah Kota Kendari tentang teori, metodologi, dan teknik perancangan peraturan perundangundangan dan kurang melibatkan stakeholder dalam penyusunan peraturan daerah, c) Budaya hukum (legal culture): kurangnya partisipasi masyarakat dalam penyusunan peraturan daerah di Kota Kendari. Sehingga diperlukan suatu metode baru dalam penyusunan peraturan daerah di Kota Kendari melalui metode Regulatory Impact Assessment. Adapun Mekanisme penyusunan peraturan daerah melalui metode Regulatory Impact Assessment adalah sebagai berikut: 1) Perumusan Masalah, 2) Identifikasi tujuan, 3) Alternatif Tindakan, 4) Analisis manfaat dan biaya, 5) Pemilihan Opsi, dan 6) Strategi implementasi kebijakan, semua tahapan dilakukan dengan Konsultasi Publik. Setelah semua tahapan dilakukan disusunlah laporan dalam bentuk Dokumen Regulatory Impact Assessment Statement (RIAS).

Guna mewujudkan penyusunan peraturan daerah yang partisipatif melalui metode Regulatory Impact Assessment (RIA) diperlukan pembinaan terhadap kompetensi dan pelatihan dibidang perancangan baik teknik maupun metodologi penyusunan peraturan daerah secara berkala bagi para perancang khususnya anggota DPRD Kota Kendari dengan cara menjalin kerja sama dengan Kementerian Hukum dan HAM wilayah Sulawesi Tenggara dan Perguruan Tinggi sehingga dapat meningkatkan kualitas para perancang dalam proses pembentukan perda di Kota Kendari dan peran aktif dari masyarakat Kota Kendari.

\section{Daftar Pustaka}

Asian Development Bank. Indonesian Regulatory Review Manual. Jakarta: Asian Development Bank dan Departemen Perindustrian dan Perdagangan, 2003.

- - - Regulatory Impact Assessment (RIA) Guide Book. Jakarta: Asian Development Bank, 2002.

Ediawan, Agus. "Pengenalan RIA." Medan: Training RIA untuk Pemerintah Kabupaten Aceh Besar pada Program RIA Aceh-The Asia Foundation, 2009.

Hamidi, Jazim. "Paradigma Baru Pembentukan dan Analisis Peraturan Daerah (Studi atas Perda Pelayanan Publik dan Perda Keterbukaan Informasi Publik)." Jurnal Hukum IUS QUIA IUSTUM 18, no. 3 (2011): 336-362.

Komite Pemantauan Pelaksanaan Otonomi Daerah (KPPOD). Daya Saing Investasi Kabupaten/Kota di Indonesia, 2005: Persepsi Dunia Usaha. Jakarta: KPPOD, 2006.

Kurnia, Mahendra Putra, Purwanto, Emilia Kuspraningrum, dan Ivan Zairani Lisi. Pedoman Naskah Akademik PERDA Partisipatif (Urgensi, Strategi, dan Proses Bagi Pembentukan Perda yang Baik). Yogyakarta: Kreasi Total Media, 2007.

Marzuki, Peter Mahmud. Penelitian Hukum. Jakarta: Kencana Prenada Media Group, 2011. 
Nasokah. "Implementasi Regulatory Impact Assessment (RIA) Sebagai Upaya Menjamin Partisipasi Masyarakat Dalam Penyusunan Peraturan Daerah." Jurnal Hukum IUS QUIA IUSTUM 15, no. 3 (2008): 443-458.

Rahardjo, Satjipto. Hukum dan Masyarakat. Bandung: Angkasa, 1986.

Soekanto, Soerjono. Faktor-Faktor Yang Mempengaruhi Penegakan Hukum. Jakarta: Rajawali Pers, 2008.

Soekanto, Soerjono, dan Sri Mamudji. Penelitian Hukum Normatif: Suatu Tinjauan Singkat. 1 ed. Jakarta: Rajawali Pers, 2014.

Tricahyo, Ibnu. "Urgensi Pengaturan tentang Pelayanan Publik." Makalah tidak dipublikasikan (2005).

Undang-Undang Nomor 12 Tahun 2011 tentang Pembentukan Peraturan PerundangUndangan, (Lembaran Negara Republik Indonesia Tahun 2011 Nomor 82, Tambahan Lembaran Negara Republik Indonesia Nomor 5234).

Undang Undang Nomor 23 Tahun 2014 tentang Pemerintahan Daerah, (Lembaran Negara Republik Indonesia Tahun 2014 Nomor 244, Tambahan Lembaran Negara Republik Indonesia Nomor 5587).

Undang-Undang Nomor 15 Tahun 2019 tentang Perubahan Atas Undang-Undang Nomor 12 Tahun 2011 tentang Pembentukan Peraturan Perundang-Undangan, (Lembaran Negara Republik Indonesia Tahun 2019 Nomor 183, Tambahan Lembaran Negara Republik Indonesia Nomor 6398).

Peraturan Menteri Dalam Negeri Nomor 80 Tahun 2015 tentang Pembentukan Produk Hukum Daerah (Berita Negara Republik Indonesia Tahun 2015 Nomor 2036).

Peraturan Menteri Dalam Negeri Nomor 120 Tahun 2018 tentang Perubahan Atas Peraturan Menteri Dalam Negeri Nomor 80 Tahun 2015 tentang Pembentukan Produk Hukum Daerah (Berita Negara Republik Indonesia Tahun 2018 Nomor 157).

Daftar Perda/Perkada dan Peraturan Menteri Dalam Negeri yang Dibatalkan/Revisi, 2016.

$\begin{array}{lll}\text { Diakses } & \text { November } & 17,\end{array}$ https://www.kemendagri.go.id/media/filemanager/2016/06/21/b/a/batal_perd a_21_juni_2016.pdf. 